\title{
Superstitions Relating to the Newt
}

\section{Edward Peacock , H. Wildon Carr , G. J. Watts , R. M. Nason \& I. Hooper}

To cite this article: Edward Peacock , H. Wildon Carr , G. J. Watts, R. M. Nason \& I. Hooper (1899) Superstitions Relating to the Newt, Folklore, 10:2, 251-254, DOI: 10.1080/0015587X.1899.9720496

To link to this article: http://dx.doi.org/10.1080/0015587X.1899.9720496

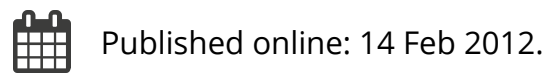

Submit your article to this journal $\square$

Q View related articles $\square$

Citing articles: 1 View citing articles 5 
MISCELLANEA.

SUPERSTITIONS RELATING TO THE NEWT.

On the roth of February, $1854, \mathrm{Mr}$. Kinahan read before the Dublin Natural History Society a paper "On the Reproduction and Distribution of the Smooth Newt and a Notice of the Popular Superstitions relating to it." It was printed in The Zoologist at the time (vol. xii., p. 4355). I forward a transcript of the portion relating to folklore :-

"This brings me to the third part of my paper, namely, the superstitions connected with this animal. There are several of them curious and interesting, as having a connection with the religious belief of the former inhabitants of this country, and are now fast dying away. In almost every part of the country we find these animals looked on with disgust and horror, if not with dread. This arises from two superstitions; one of them, common to great part of Ireland, relating chielly to the animal in its aquatic state, and which in the county of Dublin has earned for it the names of man-eater and man-keeper, though the dry ask of the county of Dublin, that is the animal in its terrestrial stage, is supposed to be equally guilty with the first mentioned, in the habit of going down the throats of those people who are so silly as either to go to sleep in the fields with their mouths open, or to drink from the streams in which the dark lewkers harbour. They are also said to be swallowed by the thirsty cattle; in consequence, the country people kill them whenever they meet with them on land, and poison the stream they are found in by putting lime into the cattle's drinking-pools. In either case the result is tho same; the reptile taking up his quarters in the interior of his victim in some way, it would puzzle a physlologist to explain how it contrives to live on the nutriment taken by the luckless individual or animal, so that, deprived of its nourishment, the latter pines away; nay, so comfortable does the newt make herself, that 
not content with living by herself, she contrives to bring up a little family. Often have $I$ been told of the man who got rid of a mamma newt and six young ones by the following recipe, which I am assured is infallible: the patient must abstain from all fluids for four-and-twenty hours, and eat only salt meats; at the expiration of that time, being very thirsty, he must go and lie open-mouthed over a running stream, the noisier the better, when the newts, dying of thirst, and hearing the music of the water, cannot resist the temptation, but come forth to drink, and of course you take care they do not get back again. The dry ask, in addition to this bad character, is also supposed to be endowed with the power of the "evil eye," children and cows exposed to its gaze wasting away. The Rev. J. Graves writes to me that in Kilkenny it is looked on as "a devil's beast," and as such is burnt. But, to compensate in some measure for its evil qualities, the dry ask is said in Dublin to bear in it a charm. Anyone desirous of the power of curing scalds or burns has only to apply the tongue along the dry ask's belly to obtain the power of curing these ailments by a touch of that organ. In Queen's County it is also used to cure discase, but in a different way; being put into an iron pot under the patient's bed it is said to effect a certain cure, though of what disease I am not quite clear."

Edward Peacock.

\section{A Sichian Festival.}

In a visit to Girgenti this winter I came to hear of a custom that seemed to me interesting as apparently a survival or metamorphosis of some rite connected with the ancient Demeter worship. I write to ask if you know whether the custom has been described by any student from personal observation, and, if so, if you can refer me to such description. The account I am sending was given me by Captain Adolf Ragusa, the proprietor of the Hotel des Temples, Girgenti, who observed it last year for the first time, but took no special notice of it, not inagining that any

- Extract from a letter to George A. Macmillan, Esq. 
particular interest could attach to it. I obtained further particulars about it from the local peasant people.

The custom is this. There is a well-kept shrine of Santa Maria delle Grazie at the cross road near the Hotel des Temples, where the road to San Biagio (a church built on the site of an ancient temple) and the modern Campo Santo branches off from the ancient road to the Porta Aurea and the temples. Flere on the 2nd Sunday in September a festival is held, and the unique feature of this festival is the slaughtering, roasting, and eating of swine before the shrine. A mass is sung at the shrine on the morning of the festival, but the procession takes place in the early afternoon, and the feasting in the afternoon and evening. The procession, consisting of processional cross, children dressed in white, garlanded with roses, and the animals for slaughter, is formed outside the church of St. Nicola, about a quarter of a mile away. I found from inquiries that the killing and eating of animals before the shrines at festivals is not an uncommon custom in parts of Sicily, but the animals are almost always only lambs and kids. Swine, however, are used as well as other animals at Porto Empedocle, four miles from Girgenti, at the Feeast of the Assumption, August I5th. I could hear of no other place where swine only were used in the feast.

25, Cumberland Terrace, Regent's Park.

H Wildon Carr. 5th March, 1899 .

\section{Burial Customs.}

You may be interested to know that some years ago, when digging a grave in Bucklebury churchyard, an old grave was disturbed and two bottles of beer unearthed. They had been buried according to a custom with the body of a person who was given to drink, and in order to give him a fair start in the land to which he had journeyed. I myself saw one of the bottles, the other being broken.

Newbury District Field Club.

G. J. Watrs. 
I was attending the burial of a well-known parishioner who died at the age of eighty-eight last month. On arriving at the house I was asked to go upstairs to say a prayer in the presence of the corpse. The room upstairs was full of guests, and also the landing. The body lay in the centre of the room, the flap of the coffin-lid turned back, and the face left visible. As each guest entered the room, he or she went up to the body, and bending over it placed the thumb against the left temple, holding it so for a moment, and then retiring. Whether anything was said or not I could not tell. I was told afterwards that the ceremony was supposed to protect those who observed it from dreaning of the deceased, or it may be of the corpse.

Greenside Vicarage, Ryton, R.S.O.,

R. M. NASON.

Newcastle-on-Tyne.

January $13^{\text {th }}, 1899$.

A superstition in connection with the dead was told me some four years ago. My informant was a lady engaged in the work of a deaconess in a parish in South London. Being asked into a house to look at a dead body, she entered, and was on the point of leaving the room, when the woman who had conducted her exclaimed that she would have bad luck if she did not touch the dead; nor was she contented until the lady had laid her hand on the brow of the corpse. This took place four or five years ago.

The woman was a middle-aged person, and if not a Londoner by birth, had at least lived in London during many years.

Rose Cottage, Seaton, Devon. 